LC-MS/MS Analysis, Antioxidant Properties and Inhibition Effect on Some Important Metabolic Enzymes of Nicotiana rustica L

\author{
Adem NECIP ${ }^{1}$, Mesut IŞIK ${ }^{2}$, Abdussamat GÜZEL ${ }^{3}$, Kasım TAKIM $^{4}$, Feyza KAYGISIZ $^{5}$ \\ ${ }^{1}$ Department of Pharmacy Services, Vocational School of Health Services, Harran University, 63200, Şanliurfa, Turkey, ${ }^{2}$ Department of \\ Bioengineering, Faculty of Engineering, Bilecik Seyh Edebali University, Bilecik, Turkey, ${ }^{3}$ Department of Pharmacy Services and Techniques, \\ Vocational School of Health Services, Inönü University, 44000, Malatya, Turkey, ${ }^{4}$ Department of Biochemistry, Veterinary Faculty, Harran \\ University, 63200, Şanlıurfa, Turkey, ${ }^{5}$ Bioengineering and Sciences, İnstitute of Science, Kahramanmaraş Sütçü İmam University 46000, \\ Turkey \\ ${ }^{1}$ https://orcid.org/0000-0002-2092-7829, ${ }^{2}$ https://orcid.org/0000-0002-4677-8104, ${ }^{3}$ https://orcid.org/0000-0001-7810-4510 \\ ${ }^{4} \mathrm{https}: / /$ orcid.org/0000-0003-4631-1982, ${ }^{5} \mathrm{https}: / /$ orcid.org/0000-0002-2899-2289 \\ 凹: ademnecip@gmail.com
}

\begin{abstract}
Being widely used since its discovery, tobacco contains many chemical substances including nitric oxide, hydrocarbons, aldehydes, phenols, quinone and semiquinone radicals, and causes the formation of oxygen-induced free radicals directly or indirectly. Therefore, it is important to know the oxidant/antioxidant properties, phenolic content of Nicotiana rustica Linn., and the effect studies on Paraoxonase (PON 1) and Acetylcholinesterase (AChE) which are important metabolic enzymes. In the study, the effect of extracts (water and methanol) of Nicotiana rustica Linn on PON 1 and AChE enzyme activity was examined. Water extract of Nicotiana rustica Linn Maras Powder with walnut, (MPWW) and methanol extract Maras Powder with Nicotiana rustica, (MPNR), Maras Powder with walnut, (MPWW) and Maras Powder with copper cauldron, (MPCC) had an inhibitory effect on $\mathrm{AChE}$ ( $\mathrm{IC}_{50}$ values in the range of 0.104$\left.0.203 \mathrm{mg} \mathrm{ml}^{-1}\right)$. Also water extract MPCC and methanol extract MPNR, MPWW and MPCC showed an inhibition effect on PON 1 (IC 50 values $0.013-0.225 \mathrm{mg} \mathrm{ml}^{-1}$ ). MPNR water extract showed the highest activity with $26 \%$ DPPH radical scavenging activity. MPCC water extract showed a 13\% ABTS radical scavenging activity.
\end{abstract}

\section{Research Article}

$\begin{array}{ll}\text { Article History } & \\ \text { Received } & : 08.01 .2021 \\ \text { Accepted } & : 18.02 .2021\end{array}$

Keywords

Maras Grass

Phenolic

Antioxidant

Enzyme inhibition

Paraoxonase

\title{
Nicotiana rustica L'nin Bazı Önemli Metabolik Enzimleri Üzerindeki İnhibisyon Etkisi, LC-MS / MS Analizi, Antioksidan Özellikleri
}

\begin{abstract}
ÖZET
Nitrik oksit, hidrokarbonlar, aldehidler, fenollar, kinon ve semikinon radikalleri gibi pek çok kimyasal maddeyi bünyesinde barındıran ve doğrudan ya da dolaylı olarak oksijen kaynaklı serbest radikal oluşumuna yol açan tütün keşfedilmesinden günümüze kadar geçen zaman içinde yaygın olarak kullanılmaktadır. Bu yüzden dolayı Nicotiana rustica L.'nin fenolik içeriğinin, antioksidan/oksidan özelliklerinin bilinmesi ve önemli metabolik enzim olan Paraoksonaz (PON 1) ve Asetilkolinesteraz (AChE) üzerine etki çalışmaları önem arzetmektedir. Çalışmada Nicotiana rustica L.'nin su ve methanol ektresinin, PON 1 ve $\mathrm{AChE}$ enzim aktivitesi üzerine etkisine bakılmış. Nicotiana rustica Linn'in su ektresi ceviz ile karıştırılmış maraş otu, (MPWW) ve methanol ektresi meşe ile karıştırılmış maraş otu (MPNR), ceviz ile karıştırılmış maraş otu (MPWW) ve bakır kazanlarında nemlendirilmiş maraş otu (MPCC) AChE üzerine inhibisyon etkisi ( $\mathrm{IC}_{50}$ değerleri $0.104-0.203 \mathrm{mg} \mathrm{ml}{ }^{-1}$ aralığında) gösterirken su ektresi MPCC ve methanol ektresi MPNR, MPWW ve MPCC ise PON 1 üzerine inhibisyon etkisi göstermiştir (IC 50 değerleri 0.013-0. $25 \mathrm{mg} \mathrm{ml}^{-1}$ ). En yüksek radikal giderme aktivitesini MPNR su ektresi \% 26 oraninda DPPH radikal giderme aktivitesi gösterirken, MPCC su ektresi \% 13 oranında ABTS radikal giderme
\end{abstract}

\section{Araştırma Makalesi}

Makale Tarihçesi

Geliş Tarihi : 08.01 .2021

Kabul Tarihi : 18.02 .2021

Anahtar Kelimeler

Maraş Otu

Fenolik

Antioksidan

Enzim inhibisyonu

Paraoksonaz 
aktivitesi göstermiştir.
To Cite: $\quad$ Necip A, Işık M, Güzel A, Takım K, Kaygısız F 2021. LC-MS/MS Analysis, Antioxidant Properties and Inhibition Effect on Some Important Metabolic Enzymes of Nicotiana rustica L. KSU J. Agric Nat 24 (5): 930-938. https://doi.org/10.18016/ ksutarimdoga.vi.856514

\section{INTRODUCTION}

Tobacco has been used in various ways since its discovery until today. Although it is mostly used by burning in the form of cigarettes today, it is also widely used in the world, directly chewing smokeless or orally. Studies have reported that most smokeless tobacco products contain substances known to be harmful such as nicotine, cadmium, and specific nitrosamines (Benowitz, 1988; Kurtul, 2005). Tobacco, which contains many chemical substances such as nitric oxide, hydrocarbons, aldehydes, phenols, quinone and semiquinone radicals, and causes the formation of oxygen-induced free radicals directly or indirectly, has been widely used since its discovery (Church, 1985). It is used as a pleasurable substance because of the nicotine alkaloid, which is found in tobacco leaves and consists of organic nitrogenous substances. Leaves of some species of Nicotiana genus such as Nicotiana tobaccum $L$. and Nicotiana rustica $L$. are used in different ways all over the world. Although there are approximately 65 species included in the Nicotiana genus, only Nicotiana tobaccum and Nicotiana rustica are used in the production of tobacco products. The main tobacco products produced for cigarettes, cigars, tobacco, pipe, snuff, shredded tobacco and chewing tobacco in the world (Davis, 1982).

Since the Nicotiana plant is grown in various regions, different culture forms have been formed depending on the environmental conditions. Therefore, different species or varieties were defined (Davis and Nielson, 1999). The dried leaves of Nicotiana rustica $L$. are used to make cigarettes, tobacco and smokeless tobacco called Maraş grass (Kurtul et al., 2005; Kurtul and Gökpinar, 2012). "Nicotiana rustica $L$ " is used under different names in many regions of the world. In Bangladesh "bit", India and Southeast Asia, "Gutkin" and also Turkey, "Maraş powder" is known by name. In addition, Nicotiana rustica $L$., known as mouth grass, mad tobacco or Hasankeyf tobacco in Turkey, is called Turkish tobacco, East Indian tobacco or Aztec tobacco in some regions. In the Southeastern Anatolia regions of Turkey, especially around Kahramanmaraş and Gaziantep, the powder obtained from the tobacco leaf called "Maraş Herb" is used through the oral mucosa (Özkul, 1997; Erenmemişoğlu 1999). Before using Nicotiana rustica $L$., the leaves are pulverized, then the ash obtained from vine, oak rod or walnut is mixed in certain proportions, crushed and slightly moistened. It is known that the ash mixed during the preparation of tobacco creates an alkaline environment and facilitates its absorption from the oral mucosa. Approximately one teaspoon of Maraş grass is moistened slightly and wrapped in cigarette paper, then placed inside the lower lip and used by sucking or chewing. This process is done throughout the day depending on the habit of the individual. Some individuals even sleep by placing Maraş grass in their mouths (Erenmemişoğlu, 1991). Due to the Nnitrosamines (DNAs) contained in tobacco, it can cause pancreatic, esophagus, lung, and oral cavity cancers in users. In addition, the heart and vascular system are negatively affected by smokeless tobacco use. There are also components in tobacco smoke that are reported to have anti-oxidative properties other than nicotine. (Nair et al., 1989; Chen and Loo, 1995; Lapenna et al., 1995; Kamisaki et al., 1997; Nilsson, 1998; Weitberg and Corvese, 1999). The studies show that PON1 inhibits oxidation of high-density lipoprotein (HDL) and low-density lipoprotein (LDL). It suggests that it has antioxidant properties as it prevents the lipid peroxide (Senti et al. 2003). Serum PON1 activities and levels are also affected by acute phase proteins, smoking, and diet. Several studies have been reported showing that PON1 levels are lower in smokers than in non-smokers. It has been reported that smoking plays a role an important for coronary heart disease (CHD). (Mackness et al., 2002; Aviram and Rosenblat, 2004; Işı et al., 2007; Huen et al., 2009).

The free oxygen radical (FOR) level is also normally kept in balance by neutralizing the body's antioxidant defense systems. If this balance is destroyed in favour of FOR, destructive reactions occur in molecules such as protein, lipid, nucleic acid. This condition, called "oxidative stress", ultimately leads to tissue damage (Çalıkoğlu, 2002; Atlan, 2006). Studies have shown that acetylcholinesterase (AChE) inhibitors used in the symptomatic treatment of Alzheimer's disease are used to protect cells from oxidative stress. It has also been emphasized that some AChE inhibitors play a role in increasing angiogenesis in cardiovascular patients. In order to prevent the occurrence of cardiovascular disease, it is important to know the important metabolic enzymes that provide protection by reducing oxidative stress in serum and tissues. PON 1 (Paraoxonase 1), one of these enzymes, inhibits the development of atherosclerosis by preventing the oxidation of lipoproteins (Kakinuma et al., 2010; Işık et al., 2017; Işık, 2020).

The aim of the study was to determine the phenolic content of Nicotiana rustica L., by LS-MS / MS method. The radical removal and metal reduction activities of MPRN, MPWW and MPCC aqueous and methanol extracts and effect on the important metabolic 
enzymes such as AChE and PON 1 were investigated.

\section{MATERIAL and METHOD}

\section{General Procedure}

BHT, BHA, Trolox, trichloroacetic acid (TCA), ABTS, $\mathrm{CuCl} 2$, neocuprin, ammonium acetate $\left(\mathrm{NH}_{4} \mathrm{Ac}\right), \mathrm{DPPH}$, Potassium ferricyanide $\left(\mathrm{K}_{3} \mathrm{Fe}(\mathrm{CN})_{6}\right)$, potassium persulfate $\left(\mathrm{K}_{2} \mathrm{~S}_{2} \mathrm{O}_{8}\right)$ were used for antioxidant studies and all solvents and chemical compounds were provided from E. Merck. LC-MS/MS analyses of 25 phenolic compounds were conducted using a Nexera model Shimadzu UHPLC connected to a tandem MS device. SIL-30AC autosampler, DGU-20A3R degasser, CTO-10ASVP column oven and LC-30AD dual pumps are used in the execution of chromatographic processes. The column temperature determined as $40^{\circ} \mathrm{C}$ in chromatographic separation was performed on a C18 intersil ODS-4 (3.0 mm x $100 \mathrm{~mm}, 2 \mu \mathrm{m})$ analytical column. The flow rate of the elution gradient generated from mobile phase A (Water, $0.1 \%$ Formic acid) and mobile phase B (Methanol, 0.1\% Formic acid) was set at a flow rate of $0.3 \mathrm{~mL} / \mathrm{min}$ and an injection volume of $2 \mu \mathrm{L}$.

\section{Herbal Material}

Maraş grass, 'Nicotiana rustica Linn, is a smokeless tobacco variety widely used in the Eastern Mediterranean region of Turkey. The leaves of this tobacco plant are pulverized and mixed with oak and walnut ash and kept in copper cauldrons slightly moistened and used for different purposes (Aral et al 2006). In this study, the powder form of Nicotiana rustica Linn plant leaves (MPNR) mixed with oak (MPWW) or mixed with walnut (MPCC) was kept in a copper cauldron with a slight moistening.

\section{Infusion Extraction}

Extractions obtained with water, methanol and ethanol solvents were used for LC-MS / MS studies. Solvent was added onto $N$. rustica (solute/solvent ratio; 1/10) and mixed in a flask with a closed mouth for 24 hours on a shaker. For water extraction, $5 \mathrm{~g}$ of $N$. rustica samples were milled to a fine powder in a mill and mixed with $50 \mathrm{~mL}$ of $30{ }^{\circ} \mathrm{C}$ water by magnetic stirrer for 15 minutes. Then Extract Whatman No. It was filtered with 1 sheet of paper. For ethanol extraction, $5 \mathrm{~g}$ of $N$. rustica samples were ground to a fine powder in a mill and mixed with $50 \mathrm{~mL}$ of ethanol. The residue was repeated under the same circumstances until the extraction solvent became colourless. The extracts obtained were filtered with Whatman No. 1 paper. Both aqueous and ethanolic extracts were placed in falcon tubes and stored at -20 ${ }^{\circ} \mathrm{C}$ until use. LC-MS / MS instrument was used for bioactive component analysis in $N$. rustica extracts. Validation studies and analysis of the method developed using 16 phenolic substances; It was made in Harran University Central Research Laboratory. It is possible to classify this phenolic compound common in plant materials as flavonoids, flavonoid glycosides, hydroxycinamic and hydroxybenzoic acids. Analysis of phenolic compounds by LC-MS / MS was carried out using a Nexera model Shimadzu HPLC coupled to a dual MS device. Liquid chromatograph LC-30AD is equipped with double pump, DGU-20A3R degasser, KTO 10AS vp column oven and SIL-30AC autosampler. Chromatographic separation was executed with the $\mathrm{C} 18$ reverse-phase analytical column Inertsil ODS-4 $(150 \mathrm{~mm} \times 4.6 \mathrm{~mm}, 3 \mu \mathrm{m})$. Column temperature was kept constant at $40 \circ \mathrm{C}$. The elution gradient was formed with mobile phase A (water, $5 \mathrm{mM}$ ammonium formate and $0.1 \%$ formic acid) and mobile phase $\mathrm{B}$ (methanol, $5 \mathrm{mM}$ ammonium formate and $0.1 \%$ formic acid). Gradient program was applied $\mathrm{t}(\mathrm{min})$ according to the following values of $\mathrm{B}$ solvent. B\%: (0.40), (20.90), (23.99), (24.40), (29.40). Solvent flow rate was applied at $0.5 \mathrm{~mL} / \mathrm{min}$ and the injection volume was set to $4 \mu \mathrm{L}$. Detection of MS was done using a mass spectrometer equipped with Shimadzu LC-MS 8040 model triple, quadrupole and ESI source operation in both positive and negative ionization modes. Calculations were made by obtaining LC-MS / MS data with Lab Solutions software (Shimadzu, Kyoto, Japan). Multiple reaction tracking (MRM) mode was used to measure analysis. Three applications were made for each compound analysis in the experiment. The first analysis was done for quantitative results. The second and third analysis were made for confirmation. Optimum Electrospray Ionization (ESI) parameters; $3500^{\circ} \mathrm{C}$ interface temperature, $250^{\circ} \mathrm{C}$ DL temperature, $400^{\circ} \mathrm{C}$ heatsink temperature, 3L / min. Nebullizer gas flow and $15 \mathrm{~L} / \mathrm{min}$. determined as the drying gas flow (Köksal et al., 2017). When calculating LC-MS / MS analysis results, it was calculated by considering the total dry matter ratio. In addition, the standard deviation $( \pm)$ value of the results was determined with the formula $=$ Analyte value result * U value $/ 100$ (Taban et al., 2013; Agar et al., 2015).

\section{Evaluation of Antioxidant Activities}

\section{Metal reducing power assay}

FRAP Iron Ions $\left(\mathrm{Fe}^{3+)}\right.$ Reduction Analysis the reducing power of $N$. rustica extracts was carried out with a modified version of Oyaizu method. (Oyaizu, 1986, Elmastaş et al., 2006; Necip and Işık, 2019). $2.5 \mathrm{~mL}$ of $1 \%$ potassium ferricyanide $\left[\mathrm{K}_{3} \mathrm{Fe}(\mathrm{CN})_{6}\right]$ and phosphate buffer $(0.2 \mathrm{M}, \mathrm{pH} 6.6)$ were added to solutions of $N$. rustica extracts $\left(10,20,40 \mu \mathrm{g} \mathrm{mL}^{-1}\right)$ in $1 \mathrm{~mL}$ of extraction solvent. The mixtures were then incubated at $50^{\circ} \mathrm{C}$ for 20 minutes. After incubation, $\mathrm{FeCl}_{3}(0.25$ $\mathrm{mL}, 0.1 \%)$ and trichloroacetic acid $(2.5 \mathrm{~mL}, 10 \%)$ were added to each mixture and centrifuged (10 minutes, 
$3000 \mathrm{rpm})$. The absorbance values of the mixture at $700 \mathrm{~nm}$ were recorded and increased absorbance indicates increased reduction capacity.

The Cuprak method based on the reduction of $\mathrm{Cu}$ (II) $\mathrm{Nc}$ to $\mathrm{Cu}$ (I) - $\mathrm{Nc}$ chelate was applied. $1 \mathrm{~mL}$ of $\mathrm{CuCl}_{2}$ $(0.01 \mathrm{M})$ solution and $1 \mathrm{~mL}$ of ammonium acetate $\left(\mathrm{NH}_{4} \mathrm{Ac}\right)$ buffer solution was added to the test tube to 1 $\mathrm{mL}$ of neocuprin (2,9-dimethyl-1,10-phenanthroline; $7.5 \times 10-3 \mathrm{M}$ alcohol $)$ and mixed by vortex. Then extracts of different concentrations $(10,20,40 \mu \mathrm{L})$ were added and the total volume was adjusted to $4 \mathrm{~mL}$ with water. After 30 minutes incubation at room temperature, the absorbance was recorded at $450 \mathrm{~nm}$ and increasing absorbance indicates an increased capacity of $\mathrm{Cu}^{++}$ion degradation (Apak et al., 2004).

\section{Radical scavenging activity (DPPH and ABTS assay)}

DPPH scavenging activity of $N$. rustica extracts and standard antioxidants was performed by the Blois method (Blois, 1958). $0.1 \mathrm{mM} \mathrm{DPPH}$ ' solution was prepared in ethanol, and $1 \mathrm{~mL}$ of this solution was taken from 10,20, $40 \mathrm{~mL}$ of stock solutions at different concentrations to make up $3 \mathrm{~mL}$ of ethanol and added to the sample solution. $0.1 \mathrm{mM}$ solution of DPPH ${ }^{*}$ in ethanol was prepared and $1 \mathrm{~mL}$ of this solution was made up to a final volume of $3 \mathrm{~mL}$. These solutions were vortexed and then incubated in the dark for 30 minutes, their absorbances measured at $517 \mathrm{~nm}$. Here, low absorbance values indicate high radical scavenging activity.

It was made by the colour change method, which indicates that the dark blue / green coloured ABTS $\cdot+$ radical has lost its radical characteristic as a result of chemical reaction with antioxidants (Re et al., 1999). The $\mathrm{ABTS}^{-+}$radical was obtained by mixing the ABTS ${ }^{+}$solution prepared with $2 \mathrm{mmolL}^{-1} \mathrm{H}_{2} \mathrm{O}$ and $2.45 \mathrm{mmolL}^{-1}$ of potassium persulfate $\left(\mathrm{K}_{2} \mathrm{~S}_{2} 0_{8}\right)$ solution at a ratio of 1:2 and incubating for 14 hours in the dark and at room temperature. Before using the $\mathrm{ABTS}^{\cdot+}$ radical, the $\mathrm{ABTS}^{\cdot+}$ solution was diluted with sodium phosphate buffer $\left(0.1 \mathrm{~mol} \mathrm{~L}^{-1}, \mathrm{pH} 7.4\right)$ to obtain an absorbance of $0.750 \pm 0.025$. Then $10,20,40 \mu \mathrm{L}$ of the stock solutions of the $N$. rustica extracts were added to the phosphate buffer until its volume became $3 \mathrm{~mL}$, then $1 \mathrm{~mL}$ of ABTS ${ }^{+}$solution was added and vortexed. These solutions were incubated, 30 minutes in the dark, and their absorbance was measured at $734 \mathrm{~nm}$. Here, low absorbance values indicate high radical scavenging activity. The radical scavenging activity was calculated using the following equation 1 .

Radical scavenging activity (\%) =

Absorbance of the control-Absorbance of the sample $\times 100$ Absorbance of the control

\section{Determination of Enzyme Activities}

In the study, the inhibitory effect of $N$. rustica extracts on AChE and hPON1 enzyme at various concentrations was investigated. IC 50 values of each extract for these enzymes were determined. The inhibitory effects of water and methanol extracts on AChE enzymes were tested by Ellman's method. Briefly, the reaction containing $50 \mu$ l of 5.5'-dithio-bis (2-nitro-benzoic) acid (DTNB), $100 \mu \mathrm{l}$ Tris-HCl buffer ( $1 \mathrm{M}, \mathrm{pH}$ 8.0) and $50 \mu \mathrm{l} \mathrm{AChE}\left(5.32 \times 10^{-3} \mathrm{U}\right)$ the solution was incubated for 15 minutes at $30^{\circ} \mathrm{C}$ with mixing (Ellman et al., 1961). Finally, the reaction was started by adding $50 \mu \mathrm{l}$ of substrate (acetylthiocholine iodide). Enzymatic activity was recorded at a wavelength of $412 \mathrm{~nm}$. hPON1 activity was measured using paraoxon (diethyl p-nitrophenyl phosphate) as a substrate. Approximately $1 \mathrm{~mL}$ of reaction mixture contains $1 \mathrm{mM} \mathrm{CaCl}_{2}$ and $50 \mathrm{mM}$ glycine / NaOH $(\mathrm{pH}$ 10.5). hPON1 activity is based on measurement of $\mathrm{p}^{-}$ nitrophenol (1 mM) at $412 \mathrm{~nm}$ (Türkeş et al., 2014; Demir et al., 2017).

\section{RESULTS and DISCUSSION}

Antioxidant properties of secondary metabolites in plants is an important parameter in terms of pharmacokinetics. Functional compounds have the potential to generate less reactive phenoxyl radicals, indicating that they have an antioxidant free radical scavenging mechanism (Perry et al., 2000). This antioxidant mechanism can be described as the ability to give hydrogen atoms from hydroxyl groups; Therefore, phenoxyl radicals gain resonance stability and a stable molecule is formed. The antioxidant effects of phenolics have been investigated on the prevention of age-related degenerative brain disorders, coronary diseases and cancer (Perry et al., 2000; Wolf, 2005; Seyoum et al., 2006). In this study, antioxidant activity of $N$. rustica extracts was compared with standard antioxidants (BHT, BHA and Trolox).

The scavenging capacity of DPPH radicals has been observed with a decrease in absorbance as a result of induction by antioxidants. They make the antioxidant molecules inactive radical by giving hydrogen proton to $\mathrm{DPPH}$ radical. As a result of this reaction, low absorbance is obtained. Therefore, DPPH as a substrate is often used to evaluate the antioxidant activity of samples or molecules (Duh et al.,1999; Chang et al., 2002). Results showed a significant decrease in the concentration of DPPH radical due to the radical scavenging capacity of both standards and $N$. rustica extracts. MPRN water extract of $N$. Rustica showed stronger DPPH removal activity than the methanol extract. Scavenging effect of $N$. rustica Maras Powder with Nicotiana rustica, (MPNR) extract and standards at the same concentration $(0.05 \mathrm{mg} \mathrm{ml}$ 1) on DPPH radical, Trolox $(58 \%)>$ BHA $(47 \%)>$ MPNR water extract $(26 \%)>\mathrm{BHT}(22 \%)$ decreased in the order. As a result of these results, N. rustica MPNR water extract has shown a significant effect on free 
radical removal. The ABTS ${ }^{\cdot+}$ radical scavenging of $N$. rustica extracts was measured and compared against standard antioxidants such as BHA, BHT and Trolox. In the method, antioxidants oxidize the ABTS ${ }^{\cdot+}$ dark radical, resulting in a reduction of the dark colour. The color change produced by this reaction is used as a parameter for measuring the antioxidant potential (Gülçin, 2012). Methanol extracts and water extracts of $N$. rustica extracts showed similar activities and the results are given in Table 1 . In a study, DPPH radical scavenging activities of four different extracts obtained from the roots of Nicotiana tabacum L were investigated. It was determined that these extracts have radical scavenging activity in the range of 30-88 $\%$ (Al-Lahham et al 2020).

Table 1. DPPH and ABTS removal activity of Nicotiana rustica Linn

Tablo 1. Nicotiana rustica Linn'in DPPH ve ABTS uzaklaştırma aktivitesi

\begin{tabular}{|l|c|c|c|c|}
\hline Samples & $\begin{array}{c}\text { DPPH assay } \\
\left.\mathrm{mg} \mathrm{ml}^{-1}\right)\end{array}$ & $\begin{array}{c}\text { ABTS a } \text { assay } \\
\left(0.2 \mathrm{mg} \mathrm{ml}^{-1}\right)\end{array}$ & $\begin{array}{c}\mathrm{AChE}^{\mathrm{b}} \mathrm{IC}_{50} \\
\left(\mathrm{mg} \mathrm{ml}^{-1}\right)\end{array}$ & $\begin{array}{c}\mathrm{PON}^{\mathrm{b}} \mathrm{IC}_{50} \\
\left(\mathrm{mg} \mathrm{ml}^{-1}\right)\end{array}$ \\
\hline BHA & $47.031 \pm 2.321$ & $98.910 \pm 3.068$ & - & - \\
\hline BHT & $21.729 \pm 1.317$ & $79.551 \pm 2.786$ & - & - \\
\hline Trolox & $57.818 \pm 3.066$ & $94.361 \pm 2.908$ & - & - \\
\hline MPNR $^{\mathrm{c}}$ water extract & $26.695 \pm 1.873$ & $5.051 \pm 0.023$ & N.D & N.D \\
\hline MPWWd water extract $^{\text {d }}$ & $5.034 \pm 0.345$ & $4.849 \pm 0.103$ & 0.104 & ND \\
\hline MPCC $^{\mathrm{e}}$ water extract & $4.508 \pm 0.293$ & $13.096 \pm 0.187$ & N.D & 0.225 \\
\hline MPNR $^{\mathrm{c}}$ methanol extract & $6.898 \pm 0.367$ & $11.132 \pm 0.148$ & 0.203 & 0.025 \\
\hline MPWW methanol extract & $3.814 \pm 0.086$ & $4.755 \pm 0.102$ & 0.167 & 0.013 \\
\hline MPCC methanol extract & $6.254 \pm 0.402$ & $12.099 \pm 0.304$ & 0.123 & 0.165 \\
\hline
\end{tabular}

aValues are expressed as percent radical scavenging activity

${ }^{b}$ Effect of Nicotiana rustica Linn on AChE and PON 1 Enzyme Activity

'Maras Powder with Nicotiana rustica, (MPNR)

dMaras Powder with walnut, (MPWW)

eMaras Powder with copper cauldron, (MPCC)

It is reduced to $\mathrm{Cu}$ (I) by the reaction of $\mathrm{Cu}$ (II) with antioxidants and transferring electrons (Apak et al., 2004). As a result of this reaction, a colour change is observed and the spectrum is formed. Based on the spectrum given by $\mathrm{Cu}$ (II) at $450 \mathrm{~nm}$, the absorbance values at $450 \mathrm{~nm}$ as a result of the reaction of $N$. rustica extracts and standard antioxidants with $\mathrm{Cu}$ (II) were recorded. Both methanol and water extracts of $N$. rustica extracts showed low activity compared to standard antioxidants and the results are given in Table 2.

Antioxidant activity of bioactive substances; prevention of radical chain reaction, binding ion catalysts of transition metals, separating peroxides, prevention of continuous hydrogen separation, metal reducing capacity and radical scavenging such as based on a variety of mechanisms (Diplock, 1997; Gulcin et al., 2002). It is the reduction of $\mathrm{Fe}^{3+}$ (ferricyanide) complex to $\mathrm{Fe}^{2+}$ form, which is an important parameter in the determination of antioxidant activity. Therefore, the Prussian blue formation of $\mathrm{Fe}^{2+}$ can be monitored by measuring at $700 \mathrm{~nm}$ (Meir et al., 1995). In this study, the yellow color of the solutions prepared for the activity turns into various shades of green and blue depending on the reducing power of the antioxidant samples. Table 3 shows the reducing power of $N$. rustica extracts compared to the standard antioxidants BHT, BHA and Trolox. It has been observed that methanol extracts have more activity than water extracts.

Table 2. Metal reducing activity (Frap and Cuprac assay) of Nicotiana rustica Linn Tablo 2. Nicotiana rustica Linn'in metal indirgeme aktivitesi (Frap ve Cuprac testi)

\begin{tabular}{|l|c|c|}
\hline Samples & Frapa assay $(0.2 \mathrm{mg} \mathrm{mL}-1)$ & ${\text { Cuprac assay }\left(0.2 \mathrm{mg} \mathrm{mL}^{-1}\right)}^{\mathrm{a}}$ \\
\hline BHA & $0.748 \pm 0.042$ & $0.487 \pm 0.065$ \\
\hline BHT & $0.521 \pm 0.033$ & $0.563 \pm 0.072$ \\
\hline Trolox & $0.537 \pm 0.028$ & $0.423 \pm 0.048$ \\
\hline MPNR $^{\mathrm{b}}$ water extract & $0.120 \pm 0.014$ & $0.149 \pm 0.022$ \\
\hline MPWW $^{\mathrm{c}}$ water extract & $0.130 \pm 0.036$ & $0.158 \pm 0.017$ \\
\hline MPCC $^{\mathrm{d}}$ water extract & $0.140 \pm 0.019$ & $0.124 \pm 0.011$ \\
\hline MPRN $^{\mathrm{b}}$ methanol extract & $0.184 \pm 0.034$ & $0.267 \pm 0.058$ \\
\hline MPWW $^{\mathrm{c}}$ methanol extract & $0.165 \pm 0.027$ & $0.221 \pm 0.072$ \\
\hline MPCC $^{d}$ methanol extract & $0.158 \pm 0.053$ & $0.178 \pm 0.013$ \\
\hline
\end{tabular}

aValues are expressed as absorbance. High absorbance indicates high reduction capacity.

bMaras Powder with Nicotiana rustica, (MPNR)

cMaras Powder with walnut, (MPWW)

dMaras Powder with copper cauldron, (MPCC) 
Table 3. Analytical parameters of the standard mixture for LC-MS/MS analysis method.

Tablo 3. $L C-M S$ / MS analiz yöntemi için standart karışımın analitik parametreleri.

\begin{tabular}{|c|c|c|c|c|c|c|c|c|}
\hline Standards & $\begin{array}{l}\text { Mainion } \\
\left(m z^{-1}\right)^{a}\end{array}$ & $\mathrm{RSD} \% \mathrm{~b}$ & $\begin{array}{l}\mathrm{LOD} / \mathrm{LOQ} \\
(\mu \mathrm{g} \mathrm{L}-1) \mathrm{c}\end{array}$ & $\begin{array}{l}\text { Recovery } \\
(\%)\end{array}$ & $\mathrm{U}^{\mathrm{d}}$ & $\mathrm{RT}$ e & $\mathrm{R}^{2} \mathrm{e}$ & Equation \\
\hline Quercetin & 300.90 & 0.0136 & $22.5 / 25.7$ & 100.130 & 0.0298 & 6.091 & 0.999 & $\mathrm{Y}=(13.7831) \mathrm{X}+(-146.951)$ \\
\hline $\begin{array}{l}\text { Acetohydroxamic } \\
\text { Acid }\end{array}$ & 43.01 & 0.0082 & $2.8 / 8.2$ & 100.075 & 0.0167 & 1.986 & 0.999 & $\mathrm{Y}=(150.982) \mathrm{X}+(23.1833)$ \\
\hline Catechin hydrate & 2.95 & .0236 & $.2 / 11.4$ & .99404 & 0.0523 & 4.958 & 0.999 & $\mathrm{Y}=(79.2933) \mathrm{X}+$ \\
\hline Vanillic Acid & 166.90 & 0.0062 & $125.5 / 142.2$ & 100.093 & 0.0208 & 6.026 & 0.997 & $\mathrm{Y}=(48.0522) \mathrm{X}+(-876.904)$ \\
\hline Resveratrol & 227.0 & 0.0131 & $9.0 / 13.6$ & 0.9985 & 0.0265 & 5.713 & 0.997 & $\mathrm{Y}=(46.4361) \mathrm{X}+(-1314.61)$ \\
\hline Fumaric Acid & 115.00 & 0.0047 & $25.2 / 31.3$ & 0.99748 & 0.0116 & 3.674 & 0.998 & $\mathrm{Y}=(20.2986) \mathrm{X}+(-762.592)$ \\
\hline Gallic acid & 168.85 & 0.0136 & $0.90 / 1.6$ & 100.004 & 0.0288 & 4.134 & 0.999 & $\mathrm{Y}=(65.3835) \mathrm{X}+(-26$ \\
\hline Caffeic Acid & 178.95 & 0.0137 & $6.3 / 10.7$ & 100.917 & 0.0254 & 5.283 & 0.996 & $\mathrm{Y}=(124.785) \mathrm{X}+(-48$ \\
\hline Floridzin Dih & 36.5 & .0564 & $1.0 / 207.0$ & 10.001 & 0.1272 & 646 & 0.998 & $.90)$ \\
\hline Oleuropein & 377.123 & 0.0694 & $0.05 / 1.0$ & 0.997 & 0.1364 & 5.643 & 0.998 & $\mathrm{Y}=(25.9240) \mathrm{X}+(-5$ \\
\hline $\begin{array}{l}\text { 4-Hydroxy Cinamic } \\
\text { Acid }\end{array}$ & 222.95 & 0.0 & $8.7 / 16.1$ & 100.16 & 281 & 5.738 & 95 & $\mathrm{Y}=(13.151)$ \\
\hline Elagic Acid & 01.00 & 0.0856 & $.101 / 0.333$ & 00.232 & 0.154 & 5.895 & 0.999 & $\mathrm{Y}=(5.25903) \mathrm{X}+(-1$ \\
\hline Myricetin & 317.00 & 0.0079 & $55.4 / 59.6$ & 0.99982 & 0.0148 & 5.858 & 0.999 & $\mathrm{Y}=(37.0934) \mathrm{X}+(26$ \\
\hline Protocatechuic acid & 152.95 & 0.0129 & $30.3 / 35.4$ & 101.070 & 0.0243 & 4.96 & 0.997 & $\mathrm{Y}=(307.55) \times+(31226.26)$ \\
\hline Silymarin & 482.00 & 0.0138 & $0.5 / 1.2$ & 0.9984 & 0.0302 & 5.987 & 0.995 & $\mathrm{Y}=(31.9969) \mathrm{X}+(-1823.79)$ \\
\hline $\begin{array}{l}\text { 2-Hydroxy } \\
\text { 1.4Naphthaquinone }\end{array}$ & 206.5 & 0.0121 & $0.5 / 1.5$ & 0.9989 & 0.0256 & 6.58 & 0.997 & $\mathrm{Y}=(203.469) \mathrm{X}+(29033.1)$ \\
\hline Pyrocatechol & 109.00 & 0.0134 & $22.7 / 28.6$ & 0.9998 & 0.0258 & 6.42 & 0.998 & $\mathrm{Y}=(32.87) \mathrm{X}+(15856)$ \\
\hline Naringenin & 270.95 & 0.0205 & $5.4 / 6.4$ & 0.99883 & 0.0521 & 6.104 & 0.995 & $\mathrm{Y}=(317.241) \mathrm{X}+(337$ \\
\hline Luteolin & 284.75 & 0.0057 & $0.5 / 2.5$ & 100.772 & 0.0174 & 6.19 & 0.997 & $\mathrm{Y}=(34.6668) \mathrm{X}+(3721.79)$ \\
\hline Kemferol & 284.75 & 0.0144 & $206.6 / 214.3$ & 0.99971 & 0.0209 & 6.288 & 0.999 & $\mathrm{Y}=(2.63905) \mathrm{X}+(-206.494)$ \\
\hline Curcumin & 369.30 & 0.0598 & $0.1 / 0.75$ & 10.121 & 0.1023 & 6.516 & 0.996 & $\mathrm{Y}=(227.706) \mathrm{X}+(-10111.1)$ \\
\hline Thymoquino & 165.08 & 0.0766 & $1.5 / 4.5$ & 0.9986 & 0.1482 & 6.632 & 0.999 & $\mathrm{Y}=(60.4553) \mathrm{X}+(2285.92)$ \\
\hline Alizarin & 239.05 & 0.035 & $65.2 / 77.5$ & 0.9667 & 0.0794 & 6.800 & 0.998 & $\mathrm{Y}=(3.97487) \mathrm{X}+(1614.23)$ \\
\hline $\begin{array}{l}\text { 4-Hydroxybenzoic } \\
\text { Acid }\end{array}$ & 136.95 & 0.0154 & $30.5 / 40.25$ & 0.99662 & 0.0426 & 6.130 & 0.998 & $\mathrm{Y}=(735.804) \mathrm{X}+(-498.102)$ \\
\hline Salicylic acid & 136.95 & 0.0124 & $4.2 / 7.6$ & 100.989 & 0.0258 & 6.104 & 0.999 & $\mathrm{Y}=(746.369) \mathrm{X}+(6072.41)$ \\
\hline
\end{tabular}

${ }_{a}^{a}$ Main ion (m/z): Molecular ions of standard compounds (m / z ratio), ${ }^{b}$ RSD: Relative standard deviation, ${ }^{c} \mathrm{LOD} / \mathrm{LOQ}(\mu \mathrm{g} / \mathrm{L})$

Determination limit / Detection limit, ${ }^{d} U(\%)$ :Relative standard uncertainty at 95\% confidence level ( $\left.k=2\right),{ }^{e} R T: R e t e n t i o n$ time,

${ }^{f} R^{2}$ : Determination coefficient

Contained in the standard mixture; Result of the LCMS / MS validation study of 25 phenolic compounds are given in Table 1. The phenolic compound composition of N.rustica analyzed by tandem mass / charge based liquid chromatographic (TDS) method was evaluated with the phenolic compounds introduced as standard. As seen in Table 1, it has been determined that the amount of vanillic acid and fumaric acid are relatively high compared to the others. LC-MS / MS results of TDS different extractions are given in Table 4. According to these results; Out of a total of 25 phenolic compounds, 16 could be detected in different extracts of TDS. 15 phenolic compounds in ethanol extract; 12 phenolic compounds in methanol extract; 15 phenolic compounds in ethanol / water (1/1) extract; 11 phenolic compounds were detected in the water extract and 13 phenolic compounds in the hydrolyzed extract. According to the results in Table 4; major phenolic compounds of TDS; It was concluded that there are pyrocatechol, vanillic acid and fumaric acid. It is also understood that 4-Hydoxycinamic acid, quercetin and caffeic acid are major secondary components. It has been determined that the phenolic content of TDS is rich in diversity but poor in quantity.

The over activity of the acetylcholinesterase (AChE) enzyme, increases the hydrolysis of the neurotransmitter acetylcholine in the cholinergic system, leading to the development of Alzheimer's disease (AD). AChE inhibitors used in the treatment of $\mathrm{AD}$ are known to protect cells from oxidative damage. It has also been emphasized that some AChE inhibitors used for this disease play a role in the increase of angiogenesis in cardiovascular patients (Kakinuma et al., 2010; Işık et al., 2017; Işık, 2019).

PON1 is an antioxidant enzyme that protects cells against the harmful effects of free radicals (Aviram and Rosenblat, 2004; Işık et al., 2015). Due to its antioxidant properties, PON1 significantly reduces lipid peroxide formation during LDL oxidation and protects HDL from oxidation by lipid peroxidation (Nishio and Watanabe, 1997; Işı et al., 2019). PON1 enzyme activities in smokers have been reported in studies. (Kurtul et al., 2014; Haj Mouhamed et al., 2010). This study found that Nicotiana rustica reduced plasma PON 1 activity. 
Table 4 Analytical parameters of MPRN ${ }^{\mathrm{a}}, \mathrm{MPWW}^{\mathrm{b}}$ and $\mathrm{MPCC}^{\mathrm{c}}$ for LC-MS/MS analysis method.

Tablo 4 LC-MS / MS analiz yöntemi için MPRNa,MPWW ${ }^{\mathrm{b}}$ and $\mathrm{MPCC}^{\mathrm{c}}$ nin analitik parametreleri.

\begin{tabular}{|c|c|c|c|}
\hline & MPRNa & MPWWb & $\mathrm{MPCC}^{\mathrm{c}}$ \\
\hline Quercetin & N.D* & N.D* & N.D* \\
\hline Acetohydroxamic acid & 54 & 32.94 & 34.75 \\
\hline Catechin hydrate & 1.62 & 0.94 & 1.19 \\
\hline Vanillic acid & 4546.43 & 3251.39 & 2808.09 \\
\hline Resveratrol & 16.2 & 1.28 & 23.12 \\
\hline Fumaric acid & 800.53 & 1163.43 & 1029.45 \\
\hline Gallic acid & N.D* & N.D* & N.D* \\
\hline Caffeic acid & 10.01 & 8 & 5.63 \\
\hline Phloridzin dyhrate & 6.43 & 5.3 & 1.5 \\
\hline Oleuropein & N.D* & N.D* & N.D* \\
\hline Hydroxycinnamic acid & 0.52 & 0.31 & 0.27 \\
\hline Ellagic acid & 1.53 & 4.35 & N.D* \\
\hline Myricetin & N.D* & N.D* & N.D* \\
\hline Protocatechuic acid & N.D* & N.D* & N.D* \\
\hline Silymarin & N.D* & N.D* & N.D* \\
\hline 2 Hyroxy 1,4-napthquinone & N.D* & N.D* & N.D* \\
\hline Bütein & 27.47 & N.D* & N.D* \\
\hline Naringenin & N.D* & N.D* & N.D* \\
\hline luteolin & N.D* & N.D* & N.D* \\
\hline Kaempferol & N.D* & N.D* & N.D* \\
\hline Curmin & N.D* & N.D* & N.D* \\
\hline Thymoquinone & N.D* & N.D* & N.D* \\
\hline Alizarin & 47.28 & 50.28 & 7.26 \\
\hline Hydroxybenzoic acid & 17.87 & 16.87 & 5.47 \\
\hline Salicylic acid & 1.3 & 7.85 & 16.74 \\
\hline
\end{tabular}

\section{N.D* Not Detection}

aMaras Powder with Nicotiana rustica, (MPNR)

bMaras Powder with walnut, (MPWW)

cMaras Powder with copper cauldron, (MPCC)

The water extract with methanol extract MPRN, MPWW and MPCC and water extract the MPWW showed an inhibitory effect on $\mathrm{AChE}$ and the results are given in Table $2\left(\mathrm{IC}_{50}\right.$ : in the range 0.104-0.203 $\mathrm{mg}$ / $\mathrm{ml}$ ). MPCC water extract and methanol extract of MPRN, MPWW and MPCC showed an inhibition effect on PON 1 ( $\mathrm{IC}_{50}$ : in the range $0.013-0.225 \mathrm{mg} / \mathrm{ml}$ ). While water extract of MPWW shows the highest inhibitory effect on $\mathrm{AChE}\left(\mathrm{IC}_{50}:\right.$ 0.104), methanol extract MPWW shows the highest inhibitory effect on PON 1. ( $\left.\mathrm{IC}_{50}: 0.013\right)$. Many studies have shown that phenolic and flavonoid compounds have antiacetylcholinesterase activity.

In the study, ellagic acid has been shown to act as a potent tyrosinase and acetylcholinesterase inhibitor (Fan et al., 2008). Phenolic compounds have neuroprotective effects and may play an important role in the pathogenesis of $\mathrm{AD}$ (Feng et al., 2009; Neagu et al., 2015; Işılk, 2019). Donepezil is known to have AChE inhibitory activity approximately 10000 times stronger than ellagic acid (Jha et al., 2018). Looking at the LSMS / MS content analysis, this study experimental results are thought to have an inhibitory effect on
$\mathrm{AChE}$ and PON 1 due to the presence of ellagic acid and other phenolic acids in Nicotiana rustica Linn.

As a result, many phenolic compounds were found in Nicotiana rustica L. content and it was determined that it had moderate antioxidant activity. It was determined that especially methanol extract of this plant has inhibitory effect on AChE and PON 1. Due to the inhibitory effect of the methanolic extract of this plant on PON 1, their use may pose a risk for the development of atherosclerosis.

\section{Statement of Conflict of Interest}

Authors have declared no conflict of interest.

\section{Author's Contributions}

The contribution of the authors is equal.

\section{REFERENCES}

Al-Lahham S, Sbieh R, Jaradat N, Almasri M, Mosa A, Hamayel A, Hammad F. 2020. Antioxidant, antimicrobial and cytotoxic properties of four different extracts derived from the roots of Nicotiana tabacum L. European Journal of Integrative Medicine, 33: 101039. 
Apak R, Güçlü K, Özyürek M, Karademir, SE. 2004. Novel Total Antioxidant Capacity Index for Dietary Polyphenols and Vitamins $\mathrm{C}$ and E, Using Their Cupric İon Reducing Capability in The Presence of Neocuproine: CUPRAC Method. Journal of Agricultural and Food Chemistry, 52 (26): 79707981.

Aral M, Ekerbicer HC, Celik M, Ciragil P, Gul M 2006. Comparison Of Effects of Smoking and Smokeless Tobacco "Maras Powder" Use on Humoral İmmune System Parameters. Mediators Inflamm 3: 85019.

Atlan N, Sepici Dinçel A, Koca C. 2006. Diabetes Mellitus ve Oksidatif Stres. Türk Biyokimya Dergisi 31: 51-6.

Aviram M, Rosenblat M. 2004. Paraoxonases 1, 2, And 3, Oxidative Stress, and Macrophage Foam Cell Formation During Atherosclerosis Development. Free Radic Biol Med 37:1304-16.

Benowitz NL. 1988. Nicotine and Smokeless Tobacco. CA Cancer J Clin 38:244-7.

Blois, M. S. 1958. Antioxidant Determinations by The Use of A Stable Free Radical. Nature 181: 1199_ 1200.

Çalıkoğlu M, Ünlü A, Bilgin R. 2002. Stabil Astımlı Hastalarda Lipid Peroksidasyonu ve Antioksidan Enzim Aktiviteleri. Solunum 4: 458-62.

Chang LW. Yen WJ, Huang SC, Duh PD 2002. Antioxidant Activity of Sesame Coat. Food Chemistry 78(3): 347-354.

Chen C, Loo G 1995. Cigarette Smoke Extract İnhibits Oxidative Modification of Low Density Lipoprotein. Atherosclerosis 112: 177-185.

Church DF, Pryor WA. 1985. Free-Radical Chemistry of Cigarette Smoke and Its Toxicological İmplications. Environ Health Perspect 64:111-26.

Davis DL, Neilson MT 1999. Tobacco: Production, Chemistry and Technology. Blackwell Science Ltd, Oxford, $467 \mathrm{~S}$.

Davis PH. 1982. Flora of Turkey. Edinburgh University Press, Edinburgh, $572 \mathrm{~S}$.

Demir Y, Işık M, Gülçin İ, Beydemir Ş. 2017. Phenolic Compounds Inhibit the Aldose Reductase Enzyme from The Sheep Kidney. Journal of Biochemical and Molecular Toxicology, 31(9): E21936.

Diplock AT. 1997. Will The 'Good Fairies' Please Prove To Us That Vitamin E Lessens Human Degenerative Disease? Free Radical Research, 275): 511-532.

Duh PD, Tu YY, Yen GC. 1999. Antioxidant Activity of Water Extract of Harng Jyur (Chrysanthemum Morifolium Ramat). LWT-Food Science And Technology, 32(5): 269-277.

Ellman GL, Courtney KD, Andres V, Featherstone RM. 1961. A New and Rapid Colorimetric Determination of Acetylcholinesterase Activity. Biochem Pharmacol 7: 88-95.

Elmastaş M, Gülçin I, Beydemir Ş, Küfrevioğlu ÖI, Aboul-Enein HY. 2006. A Study on The in Vitro
Antioxidant Activity of Juniper (Juniperus Communis L.) Fruit Extracts. Analytical Letters, 39. 47-65.

Erenmemişoğlu A, Tekol Y, Kartal M, Kurucu S. 1991. The Use of A Smokeless Tobacco in Our Country "Maraşotu" Second International Symposium of Pharmaceutical Sciences. Ankara-Turkey, June, 11- 14.

Erenmemisoğlu E. 1999. Turkish Smokeless Tobacco "Maraş Powder". Preventive Medicine, 28:616-617.

Fan P, Hay AE, Marston A, Hostettmann K. 2008. Acetylcholinesterase-inhibitory activity of linarin from Buddleja davidii, structure-activity relationships of related flavonoids, and chemical investigation of Buddleja nitida. Pharmaceutical biology, 46(9): 596-601.

Feng Y, Yang S, Du X, Zhang X, Sun X, Zha M, et al. 2009. Ellagic Acid Promotes AB42 Fibrillization and Inhibits A642-Induced Neurotoxicity, Biochem Biophys Res Commun, 390:1250-1254.

Gülçin I. 2012. Antioxidant Activity of Food Constituents: An Overview. Archives of Toxicology, 86(3): 345-391.

Gulcin I, Buyukokuroglu ME, Oktay M, Kufrevioglu O I. 2002. On The İ Vitro Antioxidative Properties of Melatonin. Journal of Pineal Research, 33(3): 167171.

Mouhamed DH, Ezzaher A, Araoud M, Neffati F, Douki W, Najjar MF. 2010. Paraoxonase 1 (PON1) Activity and Lipid Parameters in Tunisian Smokers. Ann Biol Clin (Paris) 68:143-7.

Han Y, Dorajoo R, Ke T, Ayala B, Chang X, Khor CC, ... Heng CK. 2015. Interaction Effects Between Paraoxonase 1 Variants and Cigarette Smoking on Risk of Coronary Heart Disease İn A Singaporean Chinese Population. Atherosclerosis. 240(1):40-45.

Huen K, Richter R, Furlong C, Eskenazi B, Holland N. 2009. Validation Of PON1 Enzyme Activity Assays for Longitudinal Studies. Clin Chim Acta 402:6774.

Isik B, Ceylan A, Isik R. 2007. Oxidative Stress in Smokers And Nonsmokers. Inhal Toxicol 9:767769.

Işık M. 2020. Salvia officinalis L. Etanol Ekstraktının Antikolinerjik ve Antioksidan Aktivitesi ve LCMS/MS Analizi. International Journal of Life Sciences and Biotechnology, 3(1): 51-61.

Işı k M. 2019. The Binding Mechanisms and Inhibitory Effect of Intravenous Anesthetics on Ache In Vitro And In Vivo: Kinetic Analysis and Molecular Docking. Neurochemical Research, 44(9): 21472155.

Işık M, Beydemir Ş, Demir Y, Durgun M, Türkeş C, Nasır, A., ... Akkuş M. 2019. Benzenesulfonamide Derivatives Containing Imine and Amine Groups: Inhibition on Human Paraoxonase and Molecular Docking Studies. International Journal of Biological Macromolecules. 
Işık M, Beydemir Ş, Yılmaz A, Naldan ME, Aslan H. E, Gülçin İ. 2017. Oxidative Stress and Mrna Expression of Acetylcholinesterase in The Leukocytes of Ischemic Patients. Biomedicine \& Pharmacotherapy, 87: 561-567.

Işık M, Demir Y, Kırıcı M, Demir R, Şimşek F, Beydemir Ş. 2015. Changes in The Antioxidant System in Adult Epilepsy Patients Receiving AntiEpileptic Drugs. Archives of Physiology and Biochemistry, 121(3): 97-102.

Jha AB, Panchal SS, Shah A. 2018. Ellagic Acid: Insights into Its Neuroprotective And Cognitive Enhancement Effects In Sporadic Alzheimer's Disease. Pharmacology Biochemistry and Behavior, 175: 33-46.

Kakinuma Y, Furihata M, Akiyama T, Arikawa M, Handa T, Katare RG, Sato T. 2010. Donepezil, An Acetylcholinesterase Inhibitor Against Alzheimer's Dementia, Promotes Angiogenesis in An Ischemic Hindlimb Model. Journal of Molecular and Cellular Cardiology, 48(4): 680-693.

Kamisaki Y, Wada K, Nakamoto K, Kishimoto Y, Ashida K, Itoh T 1997. Inhibition By Cigarette Smoke of Lipid Peroxidation Induced Neurotransmitter Release. Life Sci 60: 229-233.

Kurtul N, Cil MY, Pacaci SD. 2005. Serum Total Sialic Acid Levels in Smokers And Users of Smokeless Tobacco in Form of Oral Powder (Maraş Powder). J Biomed Sci 12:559-63.

Kurtul N, Çil MY, Paçacı SF. 2005. Serum Total Sialic Acid Levels in Smokers And Users of Smokeless Tobacco in Form of Oral Powder (Maras Powder). J Biomed Sci, 12:559-63.

Kurtul N, Gökpınar E. 2012. Salivary Lipid Peroxidation and Total Sialic Acid Levels in Smokers and Smokeless Tobacco Users As Mara,S Powder. Mediat Inflamm 2012:619293.

Kurtul N, Söylemez S, Çelik M. 2014. Plasma Paraoxonase and Arylesterase Activities in Smokers and Smokeless Tobacco Users As Maraş Powder. Inhalation Toxicology, 26(4): 235-239.

Lapenna D, Degioia S, Mezzetti A, Ciofani G, Consoli A, Marzio L, Cuccurullo F 1995. Cigarette Smoke, Ferritin, And Lipid Peroxidation. Am J Respir Crit Care Med 151: 431-435.

Mackness MI, Abbott C, Arrol S, Durrington PN. 1993. The Role of High-Density Lipoprotein and LipidSoluble Antioxidant Vitamins in Inhibiting LowDensity Lipoprotein Oxidation. Biochem J 294: 829-34.

Mackness MI, Mackness B, Durrington PN. 2002. Paraoxonase and Coronary Heart Disease. Atheroscler Suppl 3:49-55.

Meir, S, Kanner J, Akiri B, Philosoph-Hadas S. 1995. Determination and Involvement of Aqueous Reducing Compounds in Oxidative Defense Systems of Various Senescing Leaves. Journal of Agricultural and Food Chemistry, 43(7): 1813-
1819

Nair J, Pakhale SS, Bhide SV. 1989. Carcinogenic Tobacco Specific Nitrosamines in Indian Tobacco Products. Food Chem Toxicol 27:751-3.

Neagu E, Paun G, Albu C, Radu GL. 2015. Assessment of Acetylcholinesterase and Tyrosinase Inhibitory and Antioxidant Activity of Alchemilla Vulgaris and Filipendula Ulmaria Extracts. Journal of The Taiwan Institute of Chemical Engineers, 52: 1-6.

Necip A, Işık M. 2019. Bioactivities of Hypericum Perforatum L and Equisetum Arvense L Fractions Obtained With Different Solvents. Int J Life Sci Biotech, 2: 221-30.

Nilsson R. 1998. A Qualitative and Quantitative Risk Assessment of Snuff Dipping. Reg Toxicol Pharmacol 28:1-16.

Oyaizu, M. 1986. Studies on Products of Browning Reaction. Antioxidative Activities of Products Of Browning Reaction Prepared From Glucosamine. The Japanese Journal of Nutrition and Dietetics, 44(6): 307-315.

Ozkul Y, Donmez H, Erenmemisoglu A, Demirtas H, Imamoglu N. 1997. Induction of Micronuclei By Smokeless Tobacco on Buccal Mucosa Cells of Habitual Users. Mutagenesis, 12: 285-7.

Perry G, Raina AK, Nunomura A, Wataya T, Sayre L M, Smith MA. 2000. How İmportant İs Oxidative Damage? Lessons From Alzheimer's Disease. Free Radical Biology \& Medicine, 28(5): 831-834.

Re R, Pellegrini N, Proteggente A, Pannala A, Yang M, Rice-Evans C. 1999. Antioxidant Activity Applying an İmproved ABTS Radical Cation Decolorization Assay. Free Radical Biology And Medicine, 26(9): 1231-1237.

Senti M, Tomas M, Anglada R, et al. 2003. Interrelationship of Smoking, Paraoxonase Activity, and Leisure Time Physical Activity: A Population Based Study. Eur J Intern Med 14:17884.

Seyoum A, Asres K, El-Fiky FK. 2006. StructureRadical Scavenging Activity Relationships of Flavonoids. Phytochemistry, 67(18): 2058-2070.

Soare JR, Dinis TCP, Cunha AP, Almeida L. 1997. Antioxidant Activities of Some Extracts of Thymus Zygis. Free Radical Research, 26(5): 469-478.

Türkeş C, Söyüt H, Beydemir Ş. 2014. Effect of Calcium Channel Blockers on Paraoxonase-1 (PON1) Activity and Oxidative Stress. Pharmacological Reports, 66(1): 74-80.

Weitberg AB, Corvese D. 1999. The Effect of Epigallocatechin Galleate and Sarcophytol A on DNA Strand Breakage İnduced By Tobaccospecific Nitrosamines and Stimulated Human Phagocytes. JECCR 18:433-7.

Wolf G. 2005. The Discovery of The Antioxidant Function of Vitamin E: The Contribution of Henry A. Mattill. The Journal of Nutrition, 135(3): 363366. 